\title{
Efficacy of a fixed combination of insulin degludec and GLP-1 receptor agonist liraglutide (Xultophy) in patient with type 2 diabetes
}

Authors: Ivona Ćudina ${ }^{1}$, Lester Toni Dobrić ${ }^{1}$, Dario Rahelić ${ }^{2}$, Spomenka Ljubić ${ }^{1,2}$ (mentor)

${ }^{1}$ School of Medicine, University of Zagreb, Zagreb, Croatia

2 Vuk Vrhovac University Clinic for Diabetes, Endocrinology and Metabolic Diseases, Merkur University Hospital, Zagreb, Croatia

DOI: https://doi.org/10.26800/LV-142-supp5-20

\section{Background:}

The fixed combination of insulin degludec and liraglutide- Xultophy is a newer therapy available for treatment of type 2 diabetes (DM2). Insulin degludec is an ultralong-basal insulin analogue and liraglutide is a glucagon-like peptide-1 receptor agonist. In this case we monitor values of $\mathrm{HbA1c}$ as a marker of glycemia regulation and predictor of vascular incidents, but also fasting glucose, HDL, LDL and triglycerides were observed.

\section{Case presentation:}

A male patient, age 62, was initially admitted as a new in Diabetology clinic, due to need for better control of diabetes. Prior to the control, patient suffered from DM2 for more than 20 years, had ITM of $31.59 \mathrm{~kg} / \mathrm{m} 2$, had advanced retinopathy and ES of the heart had been implatated (2013). The bazal bolus therapy consisted of Novorapid (short-acting insulin) and Lantus (long-acting insulin). Laboratory measurements made in the morning of first control were: HbA1c $9.4 \mathrm{mmol} / \mathrm{L}$, fasting glucose (fBG) $12.2 \mathrm{mmol} / \mathrm{L}$ and postprandial glucose $17.5 \mathrm{mmol} / \mathrm{L}$. New therapy program was instructed with Xultophy being the only therapy in a regulation of hyperglycemia; had GI side effects on metformin. Next control was in three months and patient followed diet and therapy as prescribed. HbA1c and ITM were significantly reduced, with ITM being $27.18 \mathrm{~kg} / \mathrm{m} 2$ and $\mathrm{HbA} 1 \mathrm{c} 7.8 \mathrm{mmol} / \mathrm{L}$. No side effects were registred.

\section{Conclusion:}

Based on results we may conclude that this new avaliable therapy had a good impact on $\mathrm{HbA} 1 \mathrm{c}$ level and $\mathrm{fBG}$. More followings of this patient and many others are needed in order to really estimate the efficacy of Xultophy on levels of $\mathrm{HbA} 1 \mathrm{c}$ and glucose, but also impact on reducing the risk of vascular incidents.

Keywords: DM2, HbA1c, insulin degludec, liraglutide 